\title{
Breast Cyst
}

National Cancer Institute

\section{Source}

National Cancer Institute. Breast Cyst. NCI Thesaurus. Code C5315.

A cystic lesion located in breast tissue. 